\title{
AMPHIBIANS AND REPTILES ASSOCIATED WITH THE PRAIRIE DOG GRASSLANDS ECOSYSTEM AND SURROUNDING AREAS AT THE JANOS CASAS GRANDES COMPLEX, NORTHWESTERN CHIHUAHUA, MEXICO
}

\author{
Georgina Santos-Barrera ${ }^{1}$, Jesús PaCheco ${ }^{2}$ and Gerardo Ceballos ${ }^{2}$ \\ 1Museo de Zoología, Facultad de Ciencias, UNAM, A. P. 70-399, C. P. 04510, MÉXICO D.F. \\ 2 Instituto de Ecología, UNAM, A. P. 70-275, C. P. 04510, MÉXICO, D. F. \\ gsantos@ecologia.unam.mx
}

\begin{abstract}
RESUMEN
Los perros de las praderas (Cynomys ludovicianus) se consideran actualmente una especie clave, ya que forman extensas colonias que se caracterizan por presentar una gran diversidad de vertebrados asociados a ellas. Las colonias más grandes de esta especie en Norteamérica se localizan en la región de Janos, al noroeste de Chihuahua, México. En este estudio presentamos un inventario de las especies de anfibios y reptiles que habitan en los pastizales de esta región así como de los matorrales de mesquite aledaños a las colonias de perros de las praderas. Los métodos de estudio incluyeron la utilización de un sistema de trampas de caída ordenadas en cuadrícula así como el registro de encuentros visuales (VES) mediante caminatas diurnas y nocturnas. Se registraron 9 especies de anfibios y 35 de reptiles, de estas especies, 28 están definitivamente asociadas con las colonias de perros de las praderas, y 18 especies se encontraron exclusivamente en este ambiente. Por otro lado, encontramos que 13 especies habitan exclusivamente en el matorral de mesquite. Las comunidades de anfibios y reptiles en la región de Janos tienen gran importancia para la conservación ya que 16 especies de esta diversidad (1 de anfibio y 15 de reptiles) se consideran en alguna categoría de conservación. La diversidad de la herpetofauna encontrada en los pastizales de Janos es relativamente alta comparada con la de otras colonias de perros de la pradera de Norte América. Con este estudio confirmamos que las colonias de perros de las praderas son un factor importante para el sostenimiento de la diversidad biológica en los pastizales del noroeste de México y Norte América en general, tal como se observó con los mamíferos y las aves del desierto Chihuahuense.
\end{abstract}

Palabras clave: Anfibios y reptiles, colonias de perros de las praderas, pastizales, diversidad biológica, Chihuahua.

\footnotetext{
ABSTRACT

Prairie dogs (Cynomys ludovicianus) are considered a keystone species that forms extensive colonies in the grasslands of western and central North America. These colonies are characterized by high diversity of associated vertebrates. The largest colonies in North America are located in the Janos region, northwestern Chihuahua, Mexico. In this study we present an inventory of the amphibians and reptiles inhabiting at prairie dog grasslands and surrounding mesquite scrublands in the Janos region. Methods to assess the herpetofauna included the use of a combined system of pitfall traps and visual encounter surveys (VES). We found 9 species of amphibians and 35 of reptiles. Of these species, 28 were closely related to prairie dog colonies, and 18 were exclusively recorded in this habitat.
} 
Additionally, 13 species were restricted to the mesquite scrubland. The Janos amphibian and reptile communities are of conservation concern, because 16 of the included species (1 amphibian and 15 reptiles) are considered at some risk of extinction. The diversity of amphibians and reptiles in the Janos region is clearly high in comparison with other grasslands. Our results strongly support the assumption that prairie dog grasslands are important for maintaining the mammal and avian diversity in the ecosystems of the Chihuahuan desert.

Key words: Amphibians and reptiles, prairie dog colonies, grasslands, biological diversity, Chihuahua.

\section{INTRODUCTION}

Grasslands are among the most threatened ecosystems in North America, mainly because of land use changes that have transformed the landscape in a disturbed mosaic of grasslands immersed in a matrix of agricultural and pasture lands (Ceballos et al. 2005). The black-tailed prairie dog (Cynomys ludovicianus) is a species that once occupied the grasslands of a vast region from southern Canada to northern Mexico. The advance of cattle and agricultural activities have reduced prairie dog distribution to 2 to $5 \%$ of their originally range (Miller et al. 1994, MarceSanta, pers. comm.). Prairie dogs play an important role in the structure and function of the grassland ecosystem because of its influence in maintaining regional and local species diversity, to the point that they are considered keystone species in these ecosystems (Lomolino \& Smith 2003, Ceballos et al. 2005). However, very few large prairie dog colonies persist in North America. The most important remaining colony, covering 250,000 ha, is located in the Janos-Casas Grandes complex (JCGC) at northwestern Chihuahua, Mexico. We evaluated the vertebrate diversity in this grasslands-prairie dog ecosystem, as well as the semi arid mesquite scrublands of the Janos-Casas Grandes region as part of a major project aimed to understand the relationship between the prairie dog ecosystem and related vertebrate diversity (Pacheco et al. 2000, Manzano-Fischer et al. 1999, Ceballos et al. 2005, ManzanoFisher et al. 2006). The Janos-Casas Grandes region belongs to the Chihuahuan biotic province recently identified as a highly endemic area for amphibians and reptiles in northern Mexico (Ochoa-Ochoa \& Flores-Villela 2006). The biological information concerning the amphibians and reptiles in northwestern Chihuahua is scarce, previous inventories in the state have mainly focused on the montane forests, desert, and scrubland areas from central and eastern Chihuahua (Tanner 1985, 1987, 1989, Lemos-Espinal, et al. 2004, Lemos Espinal \& Smith 2007), with little or incidental information on grasslands occupied by prairie dog colonies in the extreme northwestern areas of the state (e. g. Domínguez et al. 1974). In contrast, there are some studies on the herpetofauna associated with prairie dog colonies in the US that have well documented the association of mammals and birds -and to a lesser degree the amphibian and reptile communities- to the prairie dog colonies (e.g. Campbell \& Clark 1981, Sharp \& Uresk 1990, Kretzer \& Cully 2001, Lomolino \& Smith 2003). The main intent of this paper is to report the results of an inventory of species of 
amphibians and reptiles associated to the grasslands and scrublands at the Janos region, we also discuss on conservation aspects of the amphibian and reptile species in this region.

Study area. The study area is located in the Janos Municipality in extreme northwestern Chihuahua, Mexico, about $60 \mathrm{~km}$ south of the border with the United States of America ( $30^{\circ} 55^{\prime}$ 07" N; $108^{\circ} 29^{\prime}$ 59"W; Fig. 1). The whole area encompasses about 50,000 ha, with elevation ranging from 1,300 to $1,450 \mathrm{~m}$. Climatic conditions can be described as temperate and dry seasonal with rainfalls in summer (three months), a long dry season (eight months), and a growing season of about 200 days (Royo-Márquez \& Báez-González 2001). The average annual temperature is $15.7^{\circ} \mathrm{C}$ with a difference of $14^{\circ} \mathrm{C}$ between the coldest and hottest months; annual average precipitation is $306.7 \mathrm{~mm}$ with a constant low atmospheric

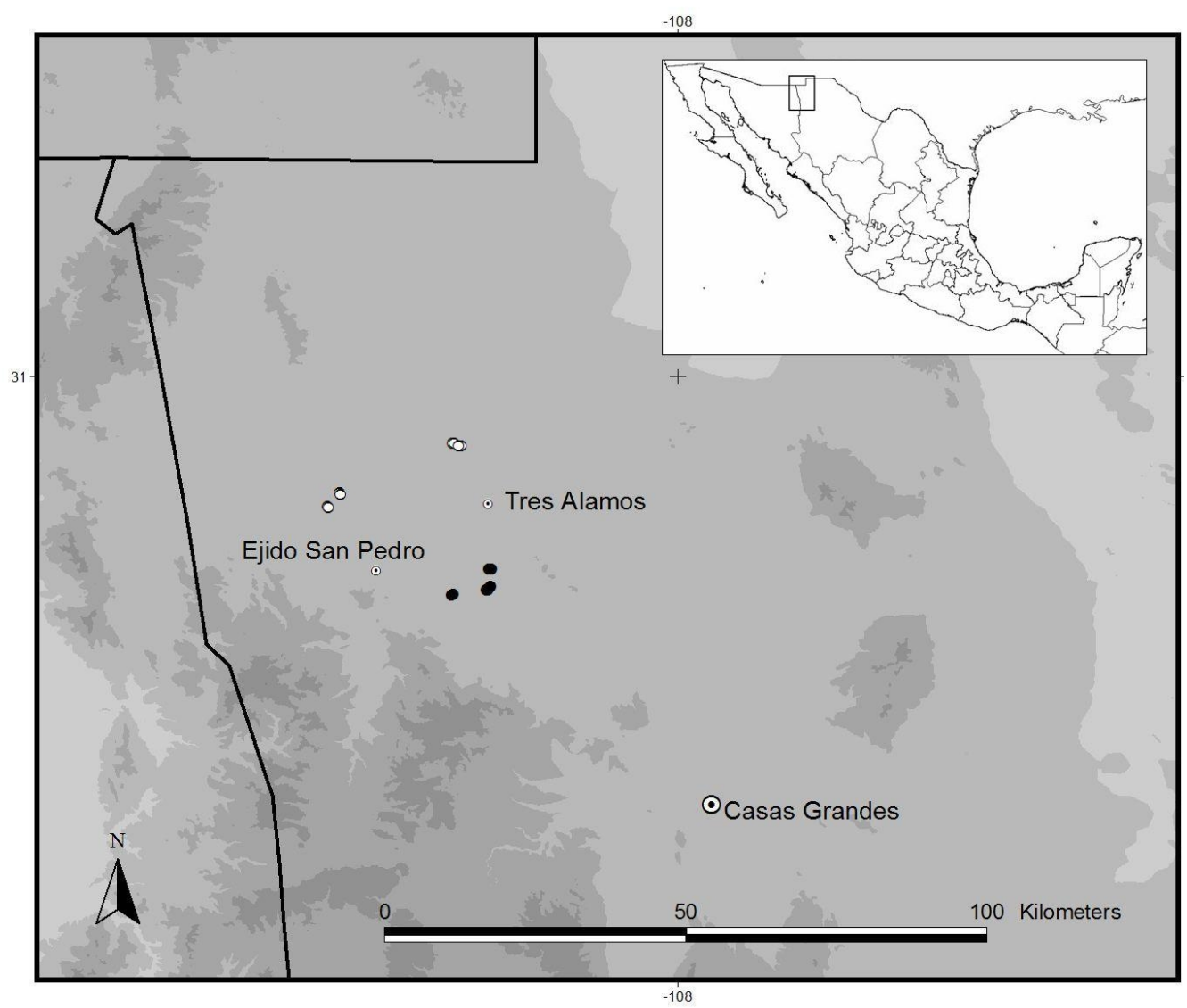

Figure. 1 Location of the Janos-Casas Grandes Complex and the grassland (black circles) and scrubland (open circles) sites sampled in this study. 
humidity (Garcia, 1981). The landscape consists of moderate open grasslands and scrublands. The plant composition of the prairie dogs colonies is of abundant grasses (e.g. blue gramma, Bouteloua gracilis, and black gramma, B. eripoda) with some areas supporting a high concentration of longleaf jointfir (Ephedra trifurca), Snakeweed (Gutierrezia imbricata), and cholla cactus (Opuntia imbricata) (RoyoMárquez \& Báez-González 2001). Scrublands are dominated by white thorn acacia (Acacia constricta), mesquite (Prosopis sp.), and cat-claw (Mimosa biuncifera). The riparian communities are composed of large trees such as sycamore (Platanus wrightii), Arizona walnut (Junglans major), and willows (Salix sp.). The area has been inhabited for more than 50 years by a Menonite community; their main activities are agriculture and livestock. In last decade electricity was introduced in these settlements causing an important negative synergistic impact to the natural systems related to the modernization of the traditional agricultural activities (Cartron et al. 2005; Ceballos et al. 2005).

\section{MATERIAL AND METHODS}

The inventory of species of amphibians and reptiles in the Janos region started informally in 1997, when the first records were compiled from transects along the area. The systematic study of the herpetological populations began on 2001 when we conducted six sampling periods including 2002 and 2004. We conducted two sample periods in each of the following years covering wet and dry seasons: 2001 (May, June), 2002 (June, September) and 2004 (April, July). For the regional inventory we studied 8 sites of grassland and 8 sites of scrubland, with additional records observed at the riparian adjacent areas. Two sampling techniques were conducted at each site. First, individual visual encounter surveys (VES) were made with two observers walking north-south direction along $1 \mathrm{~km} \times 10 \mathrm{~m}$ diurnal transects (transects reduced to $1 \mathrm{~km}$ x $6 \mathrm{~m}$ for nocturnal surveys); distance between observers was $50 \mathrm{~m}$. Diurnal surveys were conducted between 0900-1200 hr, and nocturnal surveys between 2000-2300 hr. Transects were run during three day periods, resulting in 72 hours/person/site sampled. Additionally, we established a system of pitfall-trap grids in each of the 16 grassland and mesquite scrubland sites. Each system consisted of 9 pitfall traps arranged in a $3 \times 3$ trap grid separated by a distance of $30 \mathrm{~m}$ to cover a total area of $360 \mathrm{~m}^{2}$. Each trap consisted of a standard plastic bucket (19 liters/capacity; Heyer et al. 1994). The system remained opened for three consecutive days in each sampling season. Each site was checked every morning or twice a day on extremely hot days. In order to avoid animal mortality due to the intense high temperatures, a wood cover was placed over the trap (Corn 1994). Linear transects were always located in areas adjacent to the trap grids. Specimens were captured in the study sites directly by hand, identified, examined, and then released. All individuals observed were marked according to the standard toe clipping system for 
anurans and lizards, and scale remove for snakes (Heyer et al. 1994), however data concerning changes in density population data will be reported in other paper dealing on abundance and interactions with other vertebrates (Davidson et al. in prep). Representative voucher specimens of each species were collected, preserved, and deposited in the Herpetological Collection, Museo de Zoología, Facultad de Ciencias, UNAM (MZFC). Almost all the species listed in this study are the result of our field observations. Non-literature records exist for this specific area, the nearest records come from surroundings Janos and are commented in the Discussion. A cumulative species curve was constructed by using records since 1997 to date for inventory purposes only. Nomenclature for the species list follows those of FloresVillela, (1993), Flores-Villela \& Canseco-Márquez (2004), Frost (2007) and Liner (2007).

\section{RESULTS}

Species richness and composition. We recorded 44 species of amphibians and reptiles, comprising 9 species of amphibians $(20.5 \%)$ and 35 of reptiles $(79.5 \%)$, and representing 5 and 22 genera and 3 and 11 families, respectively (Appendix 1). However, the cumulative species curve suggests that the inventory of herpetofauna remains incomplete (Fig. 2). Non-endemic species for Mexico occurs in this region, however five species and subspecies, such as the Chihuahuan collared lizard (Crotaphytus collaris), are endemic to the Chihuahuan desert.

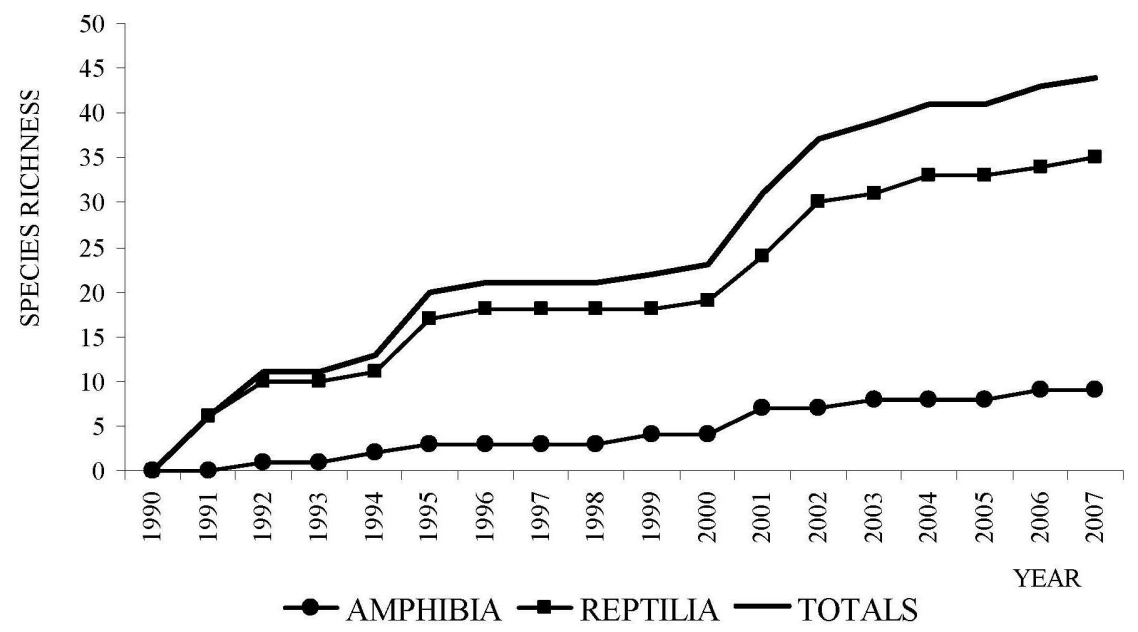

Figure. 2 Cumulative number of species of amphibians (X), reptiles (open triangles) and the whole herpetofauna (open squares) recorded in last decade at the Janos-Casas Grandes Complex, northwestern Chihuahua, Mexico. 
Distribution across habitats and seasonality. The distribution of species across habitats was heterogeneous. Seven species, such as the green toad (Anaxyrus debilis), the Western earless lizard (Holbrookia approximans), and the Mojave rattlesnake (Crotalus scutulatus), were generalists, found in both grassland and scrubland habitats; C. scutulatus was found even in the riparian habitat. Grasslands with prairie dogs supported 30 species of amphibians an reptiles (68.2\%). Six amphibians and 17 reptiles are exclusive of this ecosystem, like the Colorado River toad (Ollotis alvaria), the Horned lizard (Phrynosoma hernandesi), and the Ground snake (Sonora semiannulata, Appendix 1). In the mesquite scrubland we recorded 19 species (43.2\%) including 3 amphibians and 16 reptiles; 12 of those species such as the Spade foot toad (Spea bombifrons), the Texas horned lizard (Phrynosoma cornutum), and the Long-nosed snake (Rhinocheilus lecontei), were recorded exclusively in this last habitat. Two species of reptiles, the Southwestern fence lizard (Sceloporus cowlesi), and the Yellow mud turtle (Kinosternon flavescens) were recorded exclusively at the riparian habitat (Appendix 1).

The activity of amphibians was recorded during two complete seasons being higher at the rainy season, when most of the species were breeding in the temporal pools formed after heavy rainfalls (July-September; Santos \& Pacheco, 2004). Reptiles showed a higher activity in this season too, probably because of the abundance of insects and other small vertebrates such as mice and small lizards that represent the main part of the diet of snakes. Through the dry season (December-March), the activity of amphibians and reptiles decreased considerably in both grasslands and scrublands, and only 5 species of reptiles were observed in low abundances (Fig. 3).

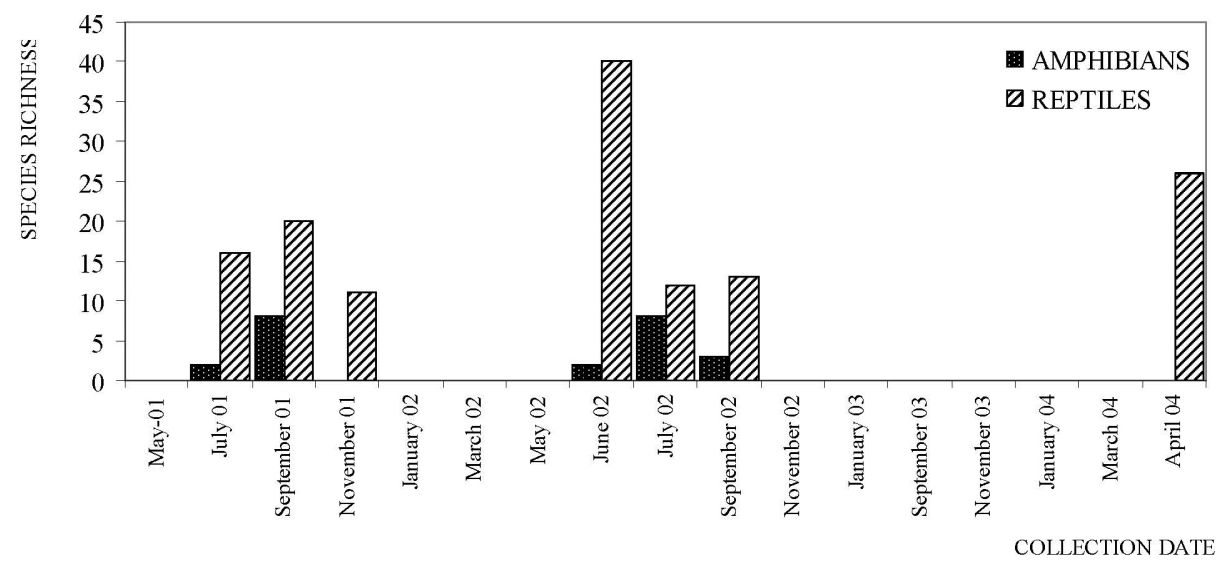

Figure 3. Seasonal activity of amphibians and reptiles during two and a half years of observations at the grasslands and scrublands of the Janos-Casas Grandes Complex. 


\section{DISCUSSION}

Diversity and conservation status of the herpetofauna. According to the cumulative species curve the diversity of the herpetofauna in the area is probably higher than indicated by our inventories. We think that the only under-represented group in this study are the snakes, which because of their habits are difficult to observe. Some species like the Southwestern black-headed snake (Tantilla hobartsmithi) were recorded only with the pitfall traps and some snake species were recorded just once. The regional diversity can increase because there are other species recorded at some surrounding Janos localities (i.e. Domínguez et al. 1974, Lemos-Espinal et al. 2004, Lemos Espinal \& Smith 2007). Two species of amphibians of probable occurrence, but never seen in this study, are the Tiger salamander (Ambystoma velasci, formerly A. tigrinum), a species commonly found in the grasslands in west central and southwestern US, and the Lowland leopard frog (Lithobates yavapaiensis), this last species possibly occurring in the mountain streams at northern Sierra de San Luis. Regarding reptiles there are other species of probable occurrence in the region as the Gila monster (Heloderma suspectum), rarely present in grasslands and woodlands but common in scrublands, and the Madrean alligator lizard (Elgaria kingii), a common inhabitant of the foothills in the forests of southwestern New Mexico (Degenhardt et al. 1996). We attribute the lack of records of these species in the grasslands to their habits; both are usually more common in foothill and rocky habitats than in lower plains. It is important to note that only grassland and scrubland species were reported in this study, however the regional diversity increases when expanded to include more montane habitats. Here, species such as the Rock rattlesnake (Crotalus lepidus), the Ridgenose rattlesnake $(C$. willardi), and the Tree lizard (Urosaurus ornatus) can be found in the margins between grasslands and foothills.

The Colorado River toad (Ollotis alvaria) is a new record for the State of Chihuahua, having previously considered to be confined to the Sonoran desert region (Santos-Barrera et al. 2006); this species was not included in the last published compilation of records of amphibians and reptiles of Chihuahua (Lemos-Espinal \& Smith 2007). Concerning the red spotted toad (Anaxyrus punctatus), the nearest known records in Chihuahua are located southward, near the city of Casas Grandes, and to the North in extreme southwestern New Mexico (Dehgenhart et al. 1996).

Fifteen species occurring at the Janos region are listed in the Red Data Book of México, (NOM-059, SEMARNAT 2003) and should be considered for conservation priority. The Janos region is a critical habitat for some species, like the green toad (Anaxyrus debilis) because there exist healthy and stable populations (Santos-Barrera $\&$ Pacheco 2004). Other species require population assessments in order to define their present conservation status, including the Ornate box turtle (Terrapene ornata), and the Massasuga (Sistrurus catenatus); both are common inhabitants of the 
grasslands and considered under the Special Protection Category (SEMARNAT, 2003).

Our results show similar trends in relation to other studies assessing the vertebrate fauna associated with prairie dog colonies in North America. Most studies have found a higher diversity in areas with prairie dog grasslands in comparison with grasslands and scrublands without prairie dogs (e.g. Campbell \& Clark 1981, Sharps \& Uresk 1990, Miller et al. 1994, Manzano-Fisher et al. 1999, Kretzer \& Cully 2001, Lomolino \& Smith, 2003, Shipley \& Reading 2006). Aside from having a high diversity of reptiles and amphibians, the prairie dog grasslands and adjacent habitat types in Janos also support a high diversity of other vertebrates, especially birds and large carnivores (Manzano-Fischer et al. 1999; 2007, Pacheco et al. 2000). Further research at prairie dogs colonies and surroundings in northern Chihuahua is still necessary to confirm the presence of other species to evaluate the present conservation status of the amphibians and reptiles in the area. Our results indicate that the prairie dog grasslands of the Janos-Casas Grandes complex support the highest diversity of amphibians and reptiles in all North American prairie dog colonies yet studied. Any efforts to protect this area would help to preserve an important ecosystem and a significant part of the native flora and fauna in northern Mexico.

Acknowledgments: We would like to thank to Hugo A. Rivas, Juan Cruzado, and Benjamín Vieyra for their field assistance. Rurik List assisted in several ways in this research. Cesar Ríos kindly helped in the preparation of the study site map. Two additional records to complete the species list where provided by Rodrigo Sierra and Eduardo Ponce-Guevara. Thanks also to J. Mendelson and three anonymous referees for their review and suggestions. This project was supported by the Universidad Nacional Autónoma de México, Instituto de Ecología (DGAPA-IN 213694), The Kaplan Fund (ECO-IE 267), the National Commission of Biodiversity (CONABIO L302), and the Declining Amphibian Population Task Force (DAPTF).

\section{LITERATURE CITED}

Campbell, T. M. \& T. W. Clark. 1981. Colony characteristics and vertebrate associates of white-tailed and black-tailed prairie dogs in Wyoming. American Midland Naturalist, 105: 269-276.

Cartron, E. J., R. E. Harness, R. C. Rogers \& P. Manzano-Fisher. 2005. Impact of concrete power poles on raptors and ravens in northwestern Chihuahua, Mexico. Pp. 357-369. 438 In: Cartron, J.E., G. Ceballos and R. S. Felger (Eds). Biodiversity, ecosystems and conservation in Northern Mexico. Oxford University Press, New York.

Ceballos, G., R. List, J. Pacheco, P. Manzano-Fischer, G. Santos \& M. Royo. 2005. Prairie dogs, cattle, and crops: diversity and conservation of the grassland-shrubland habitat mosaic in northwestern Chihuahua. Pp. 425-438 In: Cartron, J.E., G. Ceballos and R. S. Felger (Eds). Biodiversity, ecosystems and conservation in Northern Mexico. Oxford University Press, New York.

Corn, S. P. 1994. Straight-line drift fences and pitfall traps. Pp. 109-117 In: Heyer, W. R., M. A. Donelly, R. W. McDiarmid, L.C. Hayek \& M. S. Foster (Eds). Measuring and monitoring biological diversity. Standard methods for amphibians, Smithsonian Institution Press, Washington, D. C. 
Degenhardt, W. E., C. W. Painter \& A. H. Price. 1996. Amphibians and reptiles of New Mexico. University of New Mexico Press. Albuquerque. 431 pp.

Domínguez, P., T. Alvarez \& P. Huerta. 1974. Colección de anfibios y reptiles del noroeste de Chihuahua, México. Revista de la Sociedad Mexicana de Historia Natural, 35: 117-142.

Flores-Villela, O. A. 1993. Herpetofauna Mexicana. Special Publications of the Carnegie Museum of Natural History. No. 17. 1-73.

Flores-Villela, O. A. \& L. Canseco Márquez. 2004. Nuevas especies y cambios taxonómicos para la herpetofauna de México. Acta Zoológica Mexicana (n.s.) 20: 115-144.

Frost, D. R. 2007. Amphibian Species of the World: an Online Reference. Version 5.1 Electronic Database accessible at http://research.amnh.org/herpetology/amphibia/index.php. American Museum of Natural History New York, USA.

Garcia, E. 1981. Modificaciones al Sistema de Clasificación Climática de Köppen. Instituto de Geografía. UNAM. 252 pp.

Heyer, W. R., M. A. Donelly, R. W. McDiarmid, L.C. Hayek \& M. S. Foster (Eds). 1994. Measuring and monitoring biological diversity. Standard methods for amphibians, Smithsonian Institution Press, Washington, D. C.

Kretzer, J. E. \& J. F. Cully. 2001. Effects of black-tailed prairie dogs on reptiles and amphibians in Kansas short grass prairie. Southwestern Naturalist, 46: 171-177.

Lemos-Espinal, J. A., H. M. Smith \& D. Chiszar. 2004. Introducción a los anfibios y reptiles del Estado de Chihuahua. UNAM-CONABIO, México, D. F. 128 pp.

Lemos-Espinal J. A., \& H. M. Smith. 2007. Anfibios y reptiles de Chihuahua. UNAM-CONABIO, México D. F., 613 pp.

Liner, E. 2007. A checklist of the amphibians and reptiles of Mexico. Occ. Paps. Museum National Science of Lousiana State University No. 80: 1-60.

Lomolino, M. V. \& G. A. Smith, 2003. Terrestrial vertebrate communities at black-tailed prairie dog (Cynomys ludovicianus) towns. Biological Conservation, 115:89-100.

Manzano-Fischer, P. R. List \& G. Ceballos. 1999. Grassland birds in prairie-dog towns in Northwestern Chihuahua, Mexico. Studies on Avian Biology, 19: 263-271.

Manzano Fischer, P. R. List, G. Ceballos, \& J. L. Cartron. 2006. Avian diversity in a priority area for conservation: the Janos - Casas Grandes Prairie Dog Complex and adjacent habitats of Northwestern Mexico. Biodiversity Conservation 15:3801-3825.

Miller, B, G. Ceballos \& R. Reading. 1994. The prairie dog and biotic diversity. Conservation Biology, 8: 677-681.

Ochoa-Ochoa, L. M. \& O. Flores-Villela. 2006. Áreas de diversidad y endemismo de la herpetofauna mexicana. UNAM-CONABIO, México, D. F. 211 pp.

Pacheco, R. J., G. Ceballos \& R. List. 2000. Los mamíferos de la región de Janos-Casas Grandes, Chihuahua, México. Revista Mexicana de Mastozoología, 4: 71-85.

Royo-Márquez, M. \& A. D. Báez-González. 2001. Descripción del hábitat de áreas colonizadas y sin colonizar por perrito llanero (Cynomys ludovicianus) en el noroeste de Chihuahua. Técnicas Pecuarias de México, 39 (2): 89-104.

Santos-Barrera, G. \& J. Pacheco. 2004. Status of three species of toads in northwestern Mexico. Froglog, 63: 1-2.

Santos-Barrera, G., J. Cruzado, E. Ponce Guevara, R. Sierra \& J. Pacheco. 2006. Bufo alvarius (Sonoran desert toad) Geographic Distribution. Herpetological Review, 37: 98.

SEMARNAT, 2003. Norma Oficial Mexicana NOM-059-ECOL-2001, Protección ambiental- Especies nativas de México de flora y fauna silvestres- Categorías de riesgo y especificaciones para su inclusión, exclusión o cambio-Lista de especies en riesgo. Diario Oficial de la Federación 582: 1-80. 
Santos, Pacheco \& Ceballos. Herpetofauna from the Janos region, Chihuahua, Mexico

Sharp, C. C. \& D. W. Uresk. 1990. Ecological review of black-tailed prairie dogs and associated species in western South Dakota. Great Basin Naturalist, 50: 339-345.

Shipley, B. K. y R. P. Reading. 2008. A comparison of herpetofauna and small mammal diversity of black-tailed prairie dogs (Cynomys ludovicianus) colonies and non-colonized grasslands in Colorado. Journal of Arid Environments, 66: 27-41.

Tanner, W. W. 1985. Snakes of western Chihuahua. Great Basin Naturalist, 45: 615-676. 1987. Lizards and turtles of western Chihuahua. Great Basin Naturalist, 47: 383-421. 1989. Amphibians of western Chihuahua. Great Basin Naturalist, 49: 38-70.

Recibido: 6 de diciembre de 2007

Aceptado: 10 de marzo de 2008 


\section{Appendix 1}

Species of reptiles and amphibians recorded in the Janos-Casas Grandes region, Chihuahua, Mexico. HABITAT: G, grassland; S, scrubland; R, riparian. ABUNDANCE: R: rare; C: common; A, abundant. CONSERVATION (NOM 059, SEMARNAT, 2003): T =threatened; $\operatorname{Pr}=$ Under special protection. Taxonomy follows those of Flores Villela (1993); Flores Villela y Canseco Márquez, (2004), Frost (2007), and Liner (2007).

\section{HABITAT ABUNDANCE CONSERVATION}

Amphibia

Anura

Bufonidae

Ollotis alvaria

G

$\mathrm{R}$

Anaxyrus cognatus

G

Anaxyrus debilis

$\mathrm{G} / \mathrm{S}$

A

Anaxyrus punctatus

A

Pr

Anaxyrus woodhousei

G

$\mathrm{R}$

Pelobatidae

Scaphiopus couchi

G

A

Spea bombifrons

$\mathrm{S}$

C

Spea hammondi

G

C

C

Ranidae

Litobathes catesbeiana

G

$\mathrm{R}$

\section{Reptilia}

Squamata

Crotaphytidae

Crotaphytus collaris

G

$\mathrm{R}$

$\mathrm{T}$

Phrynosomatidae

Holbrookia approximans G/S

Phrynosoma cornutum

$\mathrm{G} / \mathrm{S}$

Phrynosoma hernandesi

G

C

Phrynosoma modestum

$\mathrm{S}$

Sceloporus magister

$\mathrm{S}$

Sceloporus poinsetti

$\mathrm{S}$

G

Sceloporus scalaris

$\mathrm{S}$

Sceloporus cowlesi

s

Scincidae

Uta stansburiana

S

Plestiodon obsoletus

S

$\mathrm{R}$

$\mathrm{R}$

$\mathrm{R}$

$\mathrm{R}$

Teiidae

Aspidoscelis exsanguis $\quad \mathrm{G} / \mathrm{S}$

Aspidoscelis tigris $\quad \mathrm{S}$

$\mathrm{S}$
$\mathrm{G} / \mathrm{S}$

A

Aspidosceliss uniparens

$\begin{array}{cc} & \text { A } \\ \mathrm{R} & \mathrm{C} \\ \mathrm{A} & \mathrm{T}\end{array}$

$\mathrm{R}$

C

A 
Colubridae

Arizona elegans

Coluber flagellum

Diadophis punctatus

Heterodon kennerly

Lampropeltis getula

Pituophis catenifer

Rhinocheilus lecontei

Salvadora deserticola

Sonora semiannulata

Tantilla hobartsmithi

Tantilla nigriceps

Thamnophis cyrtopsis

Thamnophis eques

Thamnophis marcianus

$\begin{array}{cc}\text { S } & \text { R } \\ \text { G } & \text { R } \\ \text { G } & \text { R } \\ \text { G } & \text { R } \\ \text { G/S } & \text { R } \\ \text { G/S } & \text { A } \\ \text { S } & \text { R } \\ \text { S } & \text { R } \\ \text { G } & \text { R } \\ \text { G } & \text { C } \\ \text { G } & \text { C } \\ \text { G } & \text { R } \\ \text { G } & \text { R } \\ \text { G } & \text { R }\end{array}$

$\mathrm{R}$

$\mathrm{R} T$

$\mathrm{R}$

R Pr

R T

Crotalidae

Crotalus atrox

Crotalus molossus

Crotalus scutulatus

G

G

Crotalus viridis

G/S

Sistrurus catenatus

G

G

A

$\mathrm{R}$

$\mathrm{R}$

$\mathrm{R}$

C

C

$\mathrm{R} \quad \mathrm{T}$

$\mathrm{R} \quad \mathrm{T}$

$\mathrm{R} T$

Testudines

Emydidae

Terrapene ornata

G

C $\mathrm{Pr}$

$\mathrm{R} \quad \mathrm{Pr}$

C Pr

A Pr

$\mathrm{R}$

$\operatorname{Pr}$

Kinosternidae 